\title{
OBLIGATIONS RELATED TO THE TRANSPORTATION OF PET ANIMALS (EU LEGISLATION) POVINNOSTI SÚVISIACE S PREPRAVOU SPOLOČENSKÝCH ZVIERAT (EURÓPSKA LEGISLATÍVA)
}

\author{
Barbara PAVLÍKOVÁ*
}

\section{Introduction}

Pets are very often integral part of the family, so it is understandable that as a family member the dog, cat or ferret travels on vacation or business trip with its owner (non-commercial movement). When owner wants to travel together with his or her pet, it requires some preparation. Most of requirements are covered by the European law, especially by two regulations - Regulation (EU) No 576/2013 and Commission Implementing Regulation (EU) No 577/2013.

The European Union, as it is generally known, is based on four fundamental freedoms - free movement of persons, capital, services and goods. Mainly within the framework of free movement of persons the question of movement of pets has arised, because the border checks at the EU territory were canceled. Now the veterinary check takes place at the external borders of the Union. Some countries in Europe, including the United Kingdom, Sweden and Norway continue to require lengthy quarantines for animals from other countries. Generally, dogs and cats may travel freely within European countries, when they are vaccinated against rabbies and blood tests demonstrate adequate level of antibod-

\section{Abstract (EN)}

A present paper deals with the question very often solved by the pet owner all around the EU Member States. It provides a closer look at the obligations associated with the travelling with the pet animals between the Member States or between the Member State and the third countries. It is focused on non-commercial transportation of pets, as vacation, trip, etc. Contribution by the means of synthesis, analysis and comparison offers an overview of the fundamental EU legislative acts in the field in question. It also addresses the issue of pet passports, the most important identification document, required for pet animals at the EU territory. Definitions of the frequently used terminology are listed.

\section{Keywords (EN)}

transportation of pets, pet animal, cat, dog, ferret, pet passport ies. Dogs must also be vaccinated against canine distemper and leptospirosis ${ }^{(1)}$.

One of harmonisation steps was taken by adoption of the Council Directive 92/65/EEC of 13 July 1992 laying down animal health requirements governing trade in and imports into the Community of animals, semen, ova and embryos not subject to animal health requirements laid down in specific Community rules referred to in Annex A (I) to Directive 90/425/EEC, in which the Council laid down the animal health requirements governing trade in and imports into the Community of animals, semen, ova and embryos not subject to animal health requirements laid down in specific Community rules referred to in Annex mentioned above. This document also set out definitions of fundamental concepts, but

POOLE, L, 2007. The Regulation and Protection of Animals Kept for Companionship: A Critical Analysis and Comparative Perspective (Chap. 4). Available at: https://www.animallaw.info/ article/the-regulation-and-protection-animals-kept-companionship-critical-analysis-and-comparative [Accessed 5 February 2015].

\section{Abstrakt (SK)}

Príspevok sa zaoberá otázkou, ktorú často riešia majitelia spoločenských zvierat vo všetkých členských štátoch EÚ. Poskytuje bližší pohlad na povinnosti spojené s cestovaním so zvieratoom medzi členskými štátmi, alebo medzi členským štátom a tretou nečlenskou krajinou. Zameriava sa na nekomerčnú prepravu, ako je napríklad dovolenka, výlet a podobne. Práca prostredníctvom syntézy, analýzy a porovnania ponúka prehlad základných legislatívnych aktov v predmetnej oblasti. Venuje sa tiež otázke tzv. pet pasu, najdôležitejšieho identifikačného dokladu, vyžadovaného pre spoločenské zvieratá na území EÚ. Možno v nej nájst' aj definície najčastejšie používanej terminológie.

\section{Klúčové slová (SK)}

preprava spoločenských zvierat, spoločenské zviera, pes, mačka, fretka, pas spoločenského zvierata

Slovak University of Agriculture in Nitra, Slovakia 
only by the means of reference to other legal acts. Of course, later it has been replaced by newer amendments, which specify the requirements in more details - it was amended for example by the Regulation No 998/2003 provides that dogs, cats and ferrets are to be accompanied by a passport when they are moved between Member States. Regulation also provided model passports for the movement of those animals to be established. Directive 92/65/EEC was amended with a view to implement the same rules to the movements of the animals concerned when traded. Rules laid down in the Regulation (EC) No 998/2003 were applicable to the non-commercial movement of pet animals into a Member State from another Member State or from first countries.

On the basis of the Regulation (EC) No 998/2003 the model passport that could be used for all movements of dogs, cats and ferrets has been firstly introduced in the Annex of the Commission Decision 2003/803/EC establishing a model passport for the intra-Community movements of dogs, cats and ferrets. The main aim of a so called „pet passport" is to provide details of certification requirements regarding anti-rabies vaccinations and other requirements concerning the health status of those animals in the format that can be easily checked by the Competent Authority, as well as for certifications of other voluntary vaccinations, so it provides all the necessary information regarding the health status of animal. This passport does not apply to animals first entering the EU from the United States, however, once animal has met the requirements for entrance into an EU Member State, its owner can contact a veterinarian in that country to apply for a passport. All tests have to be done in an EU approved laboratory and only if the blood test is successful, veterinarian will be able to issue pet with its pet passport.

\section{New Rules Governing by the Regulation (EU)} No. 576/2013 of the European Parliament and of the Council of 12 June 2013 on the Non-commercial Movement of Pet

\section{Animals and Repealing Regulation (EC)}

No. 998/2013

Firstly it is desirable to define fundamental concepts used when discussing these issues. Pet animal means according to article 3 (b) of the Regulation (EU) No 576/2013 an animal of spieces listen in the Annex 1 of this Regulation accompanying its owner or authorised person during non-commercial movement,. and which remains for the duration of such non-commercial movement under responsibility of the owner or this person. Such species under the Annex 1 are dogs, cats and ferrets, but also some species of invertebrates, birds and mammals, as they are specified in part B of the Annex 1 . Non-commercial movement is any movement which does not have as its aim either the sale of or the transder of ownership of a pet animal (art. 3(b) of the Regulation). It is for instance visit, exhibition, trip, etc. Owner is a natural person indicated as the owner in identification document and authorised person is any natural person who has authorisation in writing from the owner to carry out the non-commercial movement of the pet animal on behalf of the owner.

Each animal pet needs to be identified with the transponder what means a read-only passive radio frequency indetification device ${ }^{(2)}$. The implantation of a transponder is an invasive intervention and certain qualifications are required to carry it out. In most cases trasponders are implanted by the official or authorised veterinarians.

Owner or authorised person may be accompanied by at the most five pet animals of the species listed in part A of the Annex 1 (dogs, cats or ferrets) during a single non-commercial movement. Though, derogations can be found in article 5 (2) of the Regulation, which shall be fulfilled cumulatively. Pets shall be older than six months, the non-commercial movement is for the purpose of participating in competition, exhibition, sporting event, or training and the accompanying person has written evidence that the pet animals are registered to attend such an event or with an association organising such events.

Conditions applicable to the non-commercial movement of pet animals shall be distinguished according to whether it is a movement between two EU Member States or between Member State and a third country.

\subsection{Non-commercial Movement of Pets between the EU Member States}

Dogs, cats and ferrets may move between the EU countries only in case that four assumptions listed in article 6 of the Regulation are fulfilled. They shall be marked by the implantation of a transponder or by a clearly readable tattoo apllied before 3 July 2011, they have received an anti-rabies vaccination that complies with the validity requirements according to Annex 3 of the Regulation, they comply with any preventive health measures for diseases or infections other than rabies adopted by the Commission and they shall be accompanied by required identification documents.

Again, there are derogations available, especially from the anti-rabies vaccination condition (art. 6 (b)). They are based on the age criterion. While moving pet animals younger then 12 weeks or between 12 and 16 weeks, the authorisation may be granted by the Member State only in the case that these pets have no contact with wild animals or species susceptible to rabies or they are accompanied by their mother on whom they still depend and mother received anti-rabies vaccination. In case of adult pet animals Member States concerned

(2) The general obligation to have pet animal that is not the subject of the movement identified with the transponder is canceled in Slovakia on the basis of Admendment of the Act no. 39/2007 which came into force from 1 January 2014. 
may submit a joint application and conclude mutual agreement. List of Member States authorised to do so shall be adopted by the Commission in the form of implementing act. Futher conditions are set out in article 8 of the Regulation.

Circumstances of non-commercial movement of species listed in the part B of Annex 1 are very similar to dogs, cats and ferrets. Requirements - marking, compliance with preventive health measures and accompaniment by an identification document - are the same, the only difference may be in the concrete form.

\subsection{Non-commercial Movement of Pets between the EU Member State and a Territory or a Third Country}

Dogs, cats and ferrets from a third country shall be moved into the EU Member State only after fulfillment of five conditions and only through a travellers' point of entry. Travellers' point of entry is any area designated by Member States for the purposes of the checks. Conditions of the movement are following: marking by the means of transponder or readable tattoo, anti-rabies vaccination, compliance with preventive health measures for diseases or infections other than rabies, subjecting a rabies antibody titration test and accompaniment by the identification documents. It can be seen that the conditions almost completely coincide with the conditions of the movement between EU countries. Also the exceptions on the basis of age of the pet are very similar as those described in previous section.

One of the newly introduced obligation in association with the non-commercial movement between EU and Non-EU Member States and territories is the antibody titration test which shall not be required for dogs, cats and ferrets that are being moved directly, or following residency exlusively in one or more of those territories or third countries or if the owner or authorised person has a signed declaration that during the transit the pet animals have had no contact with risk species and remain secured within a means of transport or within the perimeter of an international airport.

Also the question of how the list of territories and third countries is being established which have made an application for entry on the list in which they demonstrate that for the dogs, cats and ferrets apply the rules, the content and effect of which are the same as those laid down in the Regulation. Between these criteria we can include for instance: an effective surveillance system for rabies for at least two years prior to the application, sufficient structure and organisation of their veterinary and control services, rules on the prevention and control of rabies in force, etc. It is adopted by the European Commission by the means of an implementing act.

In connection with the status of pet animals of one of the species listed in part B of the Annex 1 of the Regulation in the framework of non-commercial movement between EU and Non-EU Member States and territories almost the same principles are applied. In article 16 of the Regulation the list of countries and territories can be found, in which the noncommercial movement of such pets may be subject to the special conditions laid down by the national rules of those countries and territories, e.g. San Marino and Italy, Monaco and France, Andorra and Spain, Norway and Sweden and others.

\subsection{Identification documents - pet passports}

The identification document is generally know as „pet passport". It shall contain entries for the insertation of the required information:

a) the location of the tranponder or tattoo and the date of its application or the date of reading of the transponder or the tattoo, together with the alphanumeric code;

b) the name, species, breed, sex, colour, dat of birth of the pet and any other discernable features or characteristics of the pet animal;

c) the name and contat information of the owner;

d) the name, contact information and signature of the authorised veterinarian issuing or completing the identification document;

e) the signature of the owner;

f) details of the anti-rabies vaccination;

g) the date of blood sampling for the rabies antibody titration test;

h) compliance with any preventive health measures for diseases or infections other than rabies; and

i) other relevant information regarding the health status of the pet animal (art. 21(1) of the Regulation).

The authorised veterinarian issuing the identification document is obliged to keep records of the information for a minimum period of time to be determined by the competent authority, but not less than three years. Competent authority is also responsible for distribution of the blank identification documents only to authorised veterinarians.

Template of the identification document is attached to the Commission Implementing Regulation (EU) No 577/2013 on the model identification documents for non-commercial movement of dogs, cats and ferrets (Annex II).

Some countries (e.g. UK) have their rules specified in more details. To enter or re-enter the UK from another EU Member State without quarantine the pet - except being microchipped, vaccinated against rabies and blood-tested - shall also be treated against ticks and tapeworms. Pet also must be more than three months old. After required time period and before travelling, a blood test is carried out. If the results show that the pet has immunity, then it is allowed to travel. This must be within six months of the original vaccination, otherwise the owner has to start again. Only then, after all these procedures, animal is able to be given a pet passport ${ }^{(3)}$.

Pet passport is not completely standardized and, as we already mentioned, some countries require additional measures. Quarantine for a substantial period of time is the most frequent and there may be also special conditions set out by the different airlines.

(3) Pet travel: information for pet owners. Available at: https://www. gov.uk/pet-travel-information-for-pet-owners [Accessed 5 February 2015]. 
Fig 1: Pet passport cover

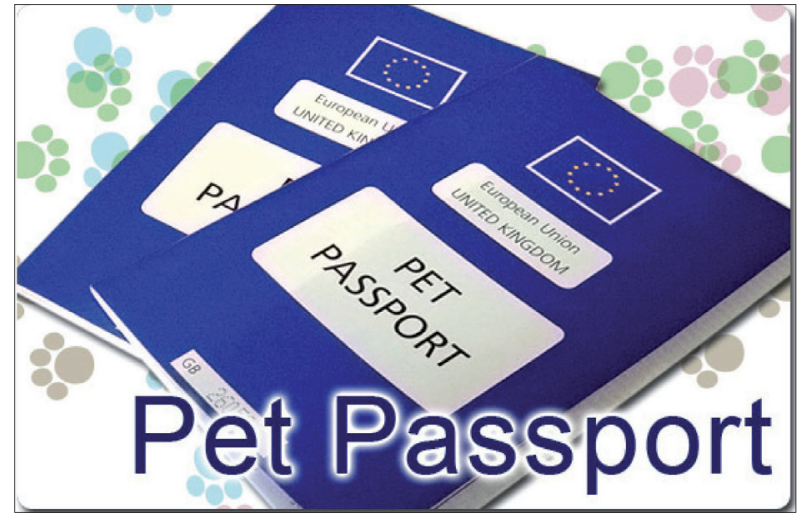

Source: http://carocat.eu/eu-pet-travel-scheme-changesfrom-29-december-2014-information-for-pet-owners/

\section{Checks at the Borders}

European Union law also deals with the issue of border controls on each consignment of live animals. Fundamental rules are laid down in the Council Directive 91/496/EEC of 151991 which lays down the principles governing the organisation of the veterinary checks on animals entering the Community from third countries. It is suplemented by the Regulation (EC) No 882/2004 on the official feed and food controls.

Animals coming from the third countries (not only pet animals) to the EU territory are subject to the veterinary checks required by the Directive 91/496/EEC. These checks are carried out at the border inspections posts by the competent authority under the responsibility of the official veterinarian. We distinguish three types of border controls:

1. a documentary checks - verification of the certificates or veterinary documents accompanying each consignment of animals;

2. an identity checks - verification by visual inspection only for consistency between the documents or certificates and the animals and for the presence and conformity of the marks which must appear on the animals;

3. a physical check - a check of the animal itself, possibly including sampling and laboratory testing, and whrere appropriate, additional checks during quarantine.

Animal, if necessary, can be placed into the quarantine according to rules provided by the Commission Decision 97/794/EC of 12 November 1997 for documentary checks, identity checks and physical checks.

However, if all import conditions are respected and there is no violation of existing rules, as well as if there is no danger to public or animal health, the official veterinarian will issue a certificate pursuant to template provided in the Annex to Commission Regulation (EC) No 282/2004 if 18 February 2004.

The European Commission has introduced information system in relation to border inspection services - TRACEC system. It is information exchange system including all the elements concerning the importation and transit of animals from the third countries. System has replaced the previous SHIFT system. TRACES means the integrated computer-
Fig 2: Pet passport contents

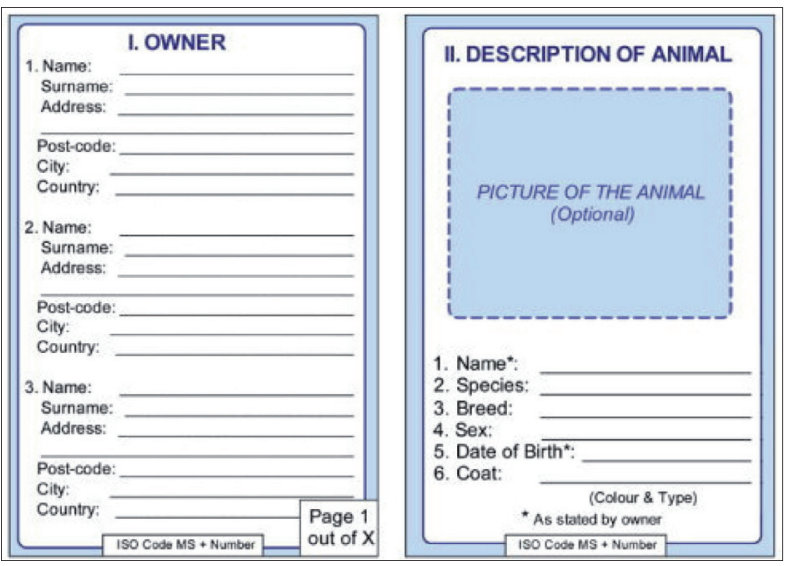

Source: http://www.katzenzeitung.eu/en/TopSubjects/travelling.html

ised veterinary system based on the provisions of Decision 2003/24/EC. It comprises all veterinary units (central, regional and local according to article $2 \mathrm{~b}$ ) of the Commission Decision 2009/821/EC) as their as set out in EU legislation.

In case that animals only pass the EU territory from one third country to another, the competent authority can decide to place them in quarantine, arrange for their reexportation or slaughter. In the case of disease occuring on the territory of a third country which represents a serious threat to animals or human health, the Commission may prohibit the importation of animals from the country in question or set special conditions to their importation or transit. The Commission as the main institution responsible for all these issues is assisted in its task by the Standing Committee on the Food Chain and Animal Health.

\section{Conclusion}

Principles of keeping of pet animals are governed not only by the law of the European Union, but also by the rules adopted under supervision of the Council of Europe. Our paper is focused on the conditions of transportation of the most frequent species of pets - dogs, cats and ferrets, but other rules in more specific fields (breeding, training, etc.) are laid down for instance in European Convention for the Protection of Pet Animals of 1987.

European Union further deals with the status of wild animals. Wild animal (pet) or exotic pet is any animal of a species that is non-native to and not normally domesticated in the EU, and that is produced, sold or kept as pets - that is, for display, amusement and/or companionship. In 2009, ENDCAP $^{(4)}$ launched an initiative at the European Parliament called „Europe's Forgotten Animals“ with the aim of improving the protection of wild animals in captivity within Member States. In 2012, following ENDCAP campaigning, „wild animals in captivity" were officially recognised by the European Council and the EU Strategy for the Protection and

\footnotetext{
(4) A pan-European Coalition of animal welfare organisations and wildlife professionals, coordinated by a Management Committee of elected individuals.
} 
Welfare of Animals, allowing for further actions and provisions to improve their protection. These steps were adopted as a consequence of the lack of consistent legislation or licensing requirements for wild pets what makes the collation of accurate information impossible. Movement of wild animal species is governed by special rules, different from those intended for domestic pet animals.

\section{References}

1. CAVILL, D. 2008. Running Your Own Boarding Kennels. London: Thanet Press, Ltd.

2. Commission Decision of 28 September 2009 drawing up a list of approved border inspection posts, laying down certain rules on the inspections carried out by Commission veterinary experts and laying down the veterinary units in Traces (2009/821/EC). Available at: http://eur-lex.europa.eu/LexUriServ/LexUriServ. do?uri=OJ:L:2009:296:0001:0058:EN:PDF [Accessed 4 February 2015].

3. Commission Implementing Regulation (EU) No 577/2013 on the model identification documents for non-commercial movement of dogs, cats and ferret, the establishment of the lists of territories and third countries and the format, layout and language requirements of the declarations attesting compliance with certain conditions provided for in Regulation (EU) No 576/2013 of the European Parliament and of the Council. Available at: http://eur-lex.europa.eu/LexUriServ/LexUriServ.do ?uri=OJ:L:2013:178:0109:0148:EN:PDF [Accessed 28 January 2015].

4. Checks on the imports of live animals. Available at: http:// europa.eu/legislation_summaries/food_safety/veterinary_ checks_and_food_hygiene/112060_en/htm [Accessed 3 February 2015].

5. Informácie pre chovatelov spoločenských zvierat a pasy spoločenských zvierat. Available at: http://www.svssr.sk/zvierata/spolocenske.asp [Accessed 25 January 2015].
6. KAHN, C.M., LINE, S., 2007. The Merck/Merial Manual For Pet Health: The complete health resource for your dog, cat, horse or other pets - in everyday language. Merck Publishing.

7. MINKE, A.G., 2010. Working abroad. E-book: August G. Minke\&Ventus Publishing ApS.

8. O'NEIL, G. 2010. A Dog as A Companion. Available at: https:// books.google.sk/books?id=bWzGAQAAQBAJ\&pg=PAll8\&dq $=$ pet + passport $\& h l=s k \& s a=X \& e i=1$ RrSVM3EGIXfaOfEgsAF\&r edir_esc $=\mathrm{y} \# \mathrm{v}=$ onepage $\& \mathrm{q}=$ pet $\% 20$ passport $\& \mathrm{f}=$ false [Accessed 4 February 2015].

9. Pet travel: information for pet owners. Available at: https:// www.gov.uk/pet-travel-information-for-pet-owners [Accessed 5 February 2015].

10. POOLE, L, 2007. The Regulation and Protection of Animals Kept for Companionship: A Critical Analysis and Comparative Perspective (Chap. 4). Available at: https://www.animallaw. info/article/tthe-regulation-and-protection-animals-keptcompanionship-critical-analysis-and-comparative [Accessed 5 February 2015].

11. Regulation (EU) No 576/2013 of the European Parliament and of the Council of 12 June 2013 on the non-commercial movement of pet animals and repealing Regulation (EC) No 998/2003. Available at: http://eur-lex.europa.eu/LexUriServ/LexUriServ.do?uri=OJ:L:2013:178:0001:0026:en:PDF [Accessed 25 January 2015].

12. Wild Pets in the European Union. Available at: http://endcap. eu/wp-content/uploads/2013/02/Report-Wild-Pets-in-theEuropean-Union.pdf [Accessed 3 February 2015].

Contact address/ Kontaktná adresa

PhDr. Mgr. Barbara Pavlíková, PhD.

Department of Law, Faculty of European Studies and Regional Development, Slovak University of Agriculture,

Tr. A. Hlinku 2, 94976 Nitra, Slovakia

e-mail: barbarapavlikova@gmail.com 